\title{
Yerli Yapım Bir Çizgi Filmin Toplumsal Cinsiyet Rolleri Açısından İncelenmesi: Pırıl
}

\section{An Analysis of a Local Production Cartoon in Terms of Gender Roles: Pirll}

\author{
Ayşenaz Ekin Duman ${ }^{\text {a, }}$, Nilüfer Koçtürk ${ }^{\text {b }}$ \\ a Yüksek Lisans Öğrencisi, Hacettepe Üniversitesi, Eğitim Fakültesi, Eğitim Bilimleri Bölümü, 06800, Ankara/Türkiye. \\ ORCID: 0000-0003-2682-0763

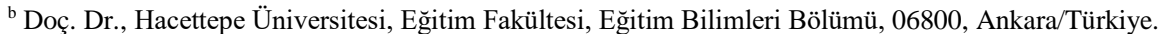 \\ ORCID: 0000-0001-6124-1842
}

\section{MAKALE BİLGİSİ}

\section{Makale Geçmişi:}

Başvuru tarihi: 02 Kasım 2020

Düzeltme tarihi: 02 Şubat 2021

Kabul tarihi: 08 Şubat 2021

Anahtar Kelimeler:

Toplumsal Cinsiyet

Toplumsal Cinsiyet Rolleri

Çizgi Film

Türkiye Yapımı

Nitel Araștırma

\section{ÖZ}

$\mathrm{Bu}$ araştırmanın amacı Pırıl çizgi filminin toplumsal cinsiyet rolleri açısından incelenmesidir. Nitel araştırma özelliği taşıyan çalışmada Pırıl çizgi filminin yayınlanan tüm bölümleri $(n=30)$ incelenmiş, veriler içerik analizi ile analiz edilip sayısallaştırılmıştır. Analiz sürecinde yüzdeler arasındaki farkın istatistiksel olarak anlamlı olup olmadığı, iki yüzde arasındaki farkın önemliliği testi ile belirlenmiştir. Bulgulara göre meslek grupları ve oyun/oyuncak seçimi açısından cinsiyetler arasındaki yüzde farkları erkek karakterlerin lehine anlamlı iken; anne/baba karakterlerinin günlük yaşam faaliyetleri bakımından yüzde farkları kadınların lehine anlamlıdır $(p<.05)$. Diğer kodlamalar (örn., isimlerin çağrıştırdığı anlamlar) yönünden cinsiyetler arasındaki yüzde farkları anlamlı değildir $(p>.05)$. Bu bağlamda Pırıl çizgi filminin meslek grupları, oyun ve oyuncak seçimi, günlük yaşam faaliyetleri yönünden geleneksel toplumsal cinsiyet rollerini sürdürmekte olduğu belirlenmiştir.

\section{A R T ICLE INFO}

\section{Article history:}

Received 02 November 2020

Received in revised form 02 February 2021

Accepted 08 February 2021

Keywords:
Gender
Gender Roles
Cartoon
Turkey Production
Qualitative Research

\section{A B S T R A C T}

The aim of this study is to examine the cartoon "Pirll" in terms of gender roles. In this qualitative study, all published episodes of the cartoon P1r1l $(n=30)$ were examined, the data was analyzed with content analysis. According to the findings, while percentage difference between the genders in terms of occupational groups and choosing games / toys was significant in favor of male characters, percentage differences of mother/father characters in terms of daily life activities were significant in favor of women $(p<.05)$. In this context, it was determined that the cartoon Prrl continues the traditional gender roles in terms of professional groups, game and toy selection as well as daily life activities.

\section{Giriş}

Birey doğduğunda üreme ve hormonal farklılıklar gibi biyolojik özelliklerini yansıtan bir yapıya sahip olmakta olup bu yapı cinsiyet olarak adlandırılmaktadır (Oakley, 2015: 23). Toplumsal cinsiyet ise bireyin içinde yaşadığ 1 kültürde doğru kabul edilen, kişiden kadın ya da erkek olarak yapması istenen görevleri kapsamaktadır (Dökmen, 2009: 20). Toplum tarafından bu cinsiyet rollerinin bireye aktarımı ise gündelik yaşama yayılmakta ve sosyalizasyon süreci ile bireyin içselleştirmesi gerçekleşmektedir (Durutürk, 2020: 54). Bu sosyalizasyon süreci de çocukluk dönemindeki oyuncak, giysi ve benzeri nesnelerde çocuğun cinsiyetini yansıttığı düşünülen rengin ve biçimin seçimi şeklinde başlamaktadır (Haskan-Avcı vd., 2019: 1093).

Çocuklar, yaklaşık üç yaş itibariyle cinsiyetin sabitliğini fark etmekte olup bu dönemde toplumsal cinsiyet görevlerini de

\footnotetext{
* Sorumlu yazar/Corresponding author.

e-posta: aysenazekin@hotmail.com
} 
yavaş yavaş algılamaktadırlar (Zembat ve Keleş, 2012: 339). $\mathrm{Bu}$ noktada aile içi etkileşimler önem kazanmakta; ebeveynlere son derece önemli görevler düşmektedir. Çünkü toplumsallaşma sürecinin bir birimi olarak aile, toplumsal cinsiyet rollerinin öğretildiği, pekiştirildiği ve aile üyelerinin toplumsal cinsiyete dair rollerini uyguladığ en önemli mikrosistemdir (Koçtürk, 2020: 364). Çocuklar, edilgen konumları ve gelişimleri dolayısıyla çoğu özelliği, özellikle aileleri olmak üzere etrafindakilerden görerek edinmektedirler. Gözlem yoluyla veya taklit yoluyla ögrenme olarak da ifade edilebilen bu durum, Bandura (1977) tarafindan öne sürülen sosyal öğrenme teorisine dayanmaktadır. Buna göre Bandura (1977: 199) yeni bir edinimin o işle doğrudan meşgul olunarak veya bir başkasının gözlemlenmesi sonucu kazanıldığını ifade etmektedir. Nitekim ögrenmenin toplumsal cinsiyet ve aile içi ilişkilerdeki yansımasına bakıldığında da çocukların ebeveynlerini taklit ederek bazı aktivitelere yöneldikleri söylenebilir (Gündüz-Kalan, 2010: 77). Örneğin, anne sürekli mutfaktayken ve ev işlerine odaklanırken; babanın bozulan nesneleri onarma gibi ev içindeki diğer işlerle uğraşması kız ve erkek çocukları farklı davranışlara yönlendirebilmektedir. Örtük bir şekilde bu davranışları içselleştiren kız çocukları, oyun ve oyuncak seçimi yaptıklarında bebek, yemek takımı gibi unsurlara yönelirken; erkek çocukları sıklıkla tamir ve araba gibi unsurlara odaklanmaktadırlar (Dinçer, 2020: 101). Konuya ilişkin Francis (2010) tarafından 3-5 yaşlarındaki çocuklarla yapılan bir araştırmada, oyuncak seçiminin cinsiyetle ilişkili olduğu ortaya konmuştur. Bulgulara göre erkek çocukları sıklıkla teknoloji ve aksiyon ile bağlantılı oyuncak seçimleri yaparken; kız çocukları kadınsılık ve bakım ile bağlantılı oyuncakları seçmişlerdir. Benzer şekilde Yağan-Güder ve Alabay (2016) tarafindan okul öncesi çocuklarla gerçekleştirilen diğer bir araştırmada kız çocuklarının en çok çay takımı, dikiş makinesi ve bebek tercih ettiği görülürken; erkek çocuklarının araba, motor ve kamyon gibi oyuncakları tercih ettikleri belirlenmiştir.

Öğrenme kuramları dışında, çocukların söz konusu davranışlara yönelmesini, diğer bir deyişle toplumsal cinsiyet rollerini kazanımlarını açıklayan pek çok kuram bulunmaktadir. Bunlardan ilki, Freud'un psikoanalitik kuramıdır. Buna göre çocuklukta, kız çocukları anneleri, erkek çocukları ise babaları ile özdeşim kurarak cinsiyet rollerine uyan kişilik özellikleri edinmektedirler (Burger, 2006: 90). Biyolojik kuram ise cinsiyet farkl1lıklarını biyolojik faktörlere göre açıklamaktadır. Bu kurama göre kadınların ve erkeklerin beyinleri başta olmak üzere diğer tüm organları birbirinden farklı özellikler sergilemektedir (Dökmen, 2009: 48). Bilişsel gelişim kuramı ise cinsiyetin oluşumunda bilişsel süreçlerin önemine dikkat çekmektedir (Martin vd., 2012: 903). Çocuk, cinsiyet edinme sürecine aktif olarak katılmakta ve elde ettiği bilgileri bilişsel süzgeçten geçirerek kendi cinsiyet rolünü biçimlendirmektedir (Dökmen, 2009: 64). Bilişsel kuram ile benzer özellikler taşıyan toplumsal cinsiyet şeması kuramına göre de çocuk kültürel olarak oluşturulan kadınsılık ve erkeksilik rollerini bilişsel olarak kodlamakta ve düzenlemektedir (Bem, 1981: 355). Örneğin, "nazik" gibi özellikler kadınsı, "atılgan” gibi özellikler de erkeksi olarak nitelendirilmektedir (Bem, 1985: 222). Son olarak, sosyal rol kuramı ise toplumda kadına ve erkeğe yüklenen rollerin davranış farklılıklarını belirlediğini savunmaktadır (Eagly, 1987: 756). Ekolojik sistem kuramı
(Bronfenbrenner, 1977: 514) da sosyal rol kuramının varsayımlarını doğrulamakla birlikte, toplumsal konulara daha sosyal ve sistemsel bir çerçeveden bakmakta ve bireyin aile, sosyal çevre, medya, toplumsal normlar, yasalar, zaman ve benzeri birçok değişken/sistem tarafından etkilendiğini varsaymaktadir.

Toplumsal cinsiyet rollerinin çocuklara aktarımında ebeveynlik davranışları etkili bir faktördür. Lindsey'e (2015: 244) göre ebeveynlik, cinsiyetçi tutumlar ile oluşturulmakta; devamında da güçlü cinsiyetçi davranışlar meydana getirmektedir. Bununla birlikte annelerin ve babaların çocuklarına yönelik toplumsal cinsiyete dayalı yönelimleri farklılık göstermektedir. Bu konuda Yağan-Güder ve GülerYıldız (2016: 3) babaların çocuklarını geleneksel toplumsal cinsiyet rollerine uygun davranışlar konusunda daha fazla yönlendirdiklerini dile getirmişlerdir. Aynı araştırmada ebeveynin kendisiyle aynı cinsiyetteki çocuğunu geleneksel toplumsal cinsiyet rollerine dayalı davranışlar konusunda daha fazla etkilediğini belirtmişlerdir. Sosyal öğrenme teorisi açısından bakıldığında çocukların oyuncak, etkinlik, giysi seçimi ve mesleklere yönelme gibi faaliyetlere ilişkin geleneksel toplumsal cinsiyet rollerine uygun seçimler yapmalarında ailenin ve toplumun yanında medyanın da büyük bir rolünün bulunduğu belirtilmektedir (GündüzKalan, 2010: 77). Okul öncesi dönemdeki çocuklar başta olmak üzere pek çok çocuğun medya ve özellikle de televizyon karşısında kalma sürelerinin yaşlarına göre fazla olduğu görülmektedir (Büyükbaykal, 2007: 32). Ertürk-Kara (2020) tarafindan anaokuluna devam etmekte olan bir grup çocuk ile yapılan araştırma sonucunda, çocukların hafta içindeki günlerde televizyonla ilgilenme sürelerinin ortalama 74.29 dakika, hafta sonundaki günlerde ise yaklaşık 78.55 dakika olduğu görülmüştür.

Televizyon, çocuğun günlük yaşamı keşfetmesi ve bir çerçeveye oturtması açısından önemli bir etkiye sahip olmakla birlikte, çocukların gelişiminde birtakım olumsuzlukları da beraberinde getirmektedir (Büyükbaykal, 2007: 35). Örneğin, çocuklar sosyal öğrenmeyi kitle iletişim araçları yoluyla da sağlamakta; bu araçlarda gördükleri olumsuz özellikler sergileyen karakterlere benzemek istemektedirler (Akça ve Koç-Çilekçiler, 2019: 406). Benzer şekilde Oruç vd. (2011: 283) uzun süre televizyon seyreden çocukların gördükleri olumsuz karakterleri ve özellikleri içselleştirmelerinin kaçınılmaz olduğunu dile getirmişlerdir. Söz konusu görüşle tutarlı olarak Yaşar ve Paksoy (2011) tarafından okul öncesi çocuklar ile gerçekleştirilen bir araştırma sonucunda saldırganlığın yer aldığı çizgi filmleri izleyen çocukların oyunlarının başında bu tür davranışları sergiledikleri görülmüştür. Benzer şekilde Christakis ve Zimmerman (2007) tarafindan okul öncesi çocuklar ile yapılan diğer bir çalışmada 2-5 yaş aralığında olan ve şiddet içerikli yayınlar izleyen erkek çocukların 7-10 yaşı kapsayan ilerleyen dönemlerde saldırgan davranışlar gösterebilecekleri saptanmıştır. Görüldüğü üzere, televizyonda yer alan içeriklerin ve bunlar yoluyla verilen iletilerin çocuklarda olumlu etkiler sağlaması çocukların psikososyal gelişimleri açısından oldukça önemli olmaktadır (Yağan-Güder vd., 2017: 97).

Yaşamda yer edinen çoğu davranış ile birlikte toplumsal cinsiyet ile ilişkili görevler ve davranışlar da televizyondaki içerikler aracılığıyla öğrenilmektedir (Muratoğlu-Pehlivan, 2019: 17). Çocuklar, söz konusu rolleri sıklıkla reklamlar, 
diziler ve çizgi filmler yoluyla edinmektedirler. Bununla birlikte çizgi filmlerin renkli ve keyifli bir görsel aktarım sağlamaları ve çizgi film karakterlerinin çeşitli sektörlerde yer alması çocuklar tarafindan daha fazla tercih edilmelerini kolaylaştırmaktadır (Kalaycı, 2015: 246). Çizgi filmlerde anne-baba rollerinin ele alınış biçimi, kız ve erkek çocukların ne tür oyuncaklar seçtikleri, yetişkinlerin hangi meslekleri icra ettikleri ve bunlara benzer pek çok tema çocukların algılarını ve günlük davranışlarını etkilemektedir. $\mathrm{Bu}$ nedenle, çizgi filmlerde toplumsal cinsiyete dayalı eşitsizliği destekleyen unsurların yer almaması çocukların gelişimleri açısından fazlaca önemli olmaktadır. Konuya dair gerçekleştirilen bazı araştırmalarda çizgi filmlerde erkek karakterlerin bulunma oranının kadın karakterlerinkinden daha fazla olduğu görülmüştür (Aley ve Hahn, 2020; Leaper vd., 2002; Martin, 2017; Smith vd., 2012; Walsh ve Leaper, 2020). Ayrıca bu araştırmaların bazılarında erkeklerin güç ve fiziksel saldirganlık (Leaper vd., 2002; Walsh ve Leaper, 2020) kadınların ise kibar, destekleyici ve romantik davranışlar (Leaper vd., 2002) ile ilişkilendirildiklerine dikkat çekilmiştir.

Çizgi filmlerde toplumsal cinsiyet rollerine dayalı iletilerin ne şekilde ve ne sıklıkta verildiğine dair sorular, Türkiye'de de araştırma konusu olmuştur. Konuya dair gerçekleştirilen Pepee (Kalayc1, 2015) ve Niloya (Yağan-Güder vd., 2017) çizgi filmlerinin incelendiği araştırmalarda anne rolündeki karakterlerin sıklıkla evde, mutfakta görüldükleri ve çocuklarla ilgilendikleri; baba rolündeki karakterlerin ise ev dışındaki alanlarda yer aldıkları belirlenmiştir. Aynı araştırmalarda kadın karakterlerin pembe ve benzeri renkte giysilerle, erkek karakterlerin ise mavi ve tonları giysilerle resmedildikleri dikkat çekmiştir. Benzer şekilde Türkiye yapımı çizgi filmlerin toplumsal cinsiyet açısından değerlendirildiği bazı çalışmalarda (Deniz, 2019; Ünlü, 2017) anne rollerinin sıklıkla ev içinde bulundukları, yemek yaptıkları, çocuklarıyla ilgilendikleri görülürken; baba karakterlerinin ev dışındaki alanda daha fazla yer aldıkları ve daha çok onarım gibi faaliyetlerle uğraştıkları belirlenmiştir. Ayrıca kız çocuklarının daha çok mutfak işlerine destek oldukları, erkek çocuklarının onarım ve bahçe işleri gibi işlerde bulundukları saptanmıştır (Deniz, 2019; Ünlü, 2017). Söz konusu bulgularla paralel olarak, Salkaya (2020) tarafından çocuk kanallarındaki unsurlar üzerinde yapılan araştırma sonucunda çizgi filmlerde kız çocuklarının geleneksel toplumsal cinsiyet rollerine dayalı davranışlarının erkeklere kıyasla daha çok ön plana çıkarıldığı görülmüştür. Tüm bunlardan hareketle, çizgi filmlerde yer alan geleneksel toplumsal cinsiyet rollerine dayalı unsurların çocukların oyun-oyuncak seçimleri, arkadaşlık ilişkisi, anne-baba olmak ile ilgili algılar gibi bilişsel ve davranış örüntülerini etkilediği söylenebilir. Nitekim Oruç vd. (2011: 283) henüz soyut işlemler dönemine geçmeyen, hayal ve gerçek arasındaki ince çizgiyi fark edemeyen çocukların kişilik gelişimleri ve benlik süreçlerinin çizgi filmlerden etkilenebileceğini belirtmişlerdir. Bununla birlikte Gökçearslan'a (2010: 5205) göre çocukların çizgi film tercihleri cinsiyet yönünden farklılaşmakta olup erkek çocukları şiddet temalı çizgi filmleri seyretmeyi seçerken, kız çocukları daha çok duygusal ve romantik temalı çizgi filmleri seyretmeyi tercih etmektedirler. Dolayısı ile çocukların çizgi film seçimlerinin geleneksel toplumsal cinsiyet rollerine dayalı iletilerle şekillendiği söylenebilir.
Özetle, çizgi filmler çocuklar tarafından ilgiyle seyredilmeye devam etmekte ve bu çizgi filmlerde toplumsal cinsiyet kalıpyargıları sıklıkla yer almaktadır.

Tüm dünyanın 2020 yllından beri Covid-19 pandemi sürecinden geçtiği (WHO, 2020) ve çocukların evde normalden daha fazla kaldıkları düşünüldüğünde, televizyona ve internet kanallarına olan yönelimin arttığı tahmin edilmektedir. Yaşları gereği evde kalmaktan fazlaca etkilenebilecek çocukların en çok tercih edecekleri aracın ise çizgi filmler olacağı düşünülmektedir. Bu doğrultuda, yerli bir kanal olan TRT Çocuk'ta hâlihazırda yayınlanmakta olup Youtube internet kanalından ödül alan Pırıl çizgi filminin (Tarnet, 2020) toplumsal cinsiyet rolleri açısından incelenmesinin önemli olduğu düşülmektedir. Pırıl çizgi filminin toplumsal cinsiyet rolleri bakımından incelenmek istenmesinin ilk sebebi, araştırmanın yapıldığı dönemde bu çizgi filmin televizyonda yayınlanıyor olması ve Youtube kanalında yüksek bir görüntülemeye ulaşmasıdır. Bununla birlikte çizgi filmin daha önceki çalışmalarda ele alınmayan kodlamalar (örn., karakter isimlerinin çağrıştırdığı anlamlar) bakımından değerlendirilebileceği ve elde edilecek olan bulgunun alanyazına yeni bir araştırma sorusu olarak katkı getireceği düşünülmektedir. Özetle, Pırıl çizgi filminde yer alan toplumsal cinsiyet bakış açısının ve kalıpyargılarının belirlenmesinin hem Türkiye'deki çizgi filmlerdeki mevcut durumun ortaya konulmasına bir katkı sağlayacağı hem de ailelere rehberlik hizmeti sunarken önerilebilecek/önerileme yecek bir kaynak olabileceği düşünülmektedir. Bu doğrultuda bu çalışmanın amacı, yerli bir kanal olan TRT Çocuk'ta hâlihazırda yayınlanmakta olup Youtube internet kanalından ödül alan Pırıl çizgi filminin toplumsal cinsiyet rolleri açısından incelenmesidir. Bu bağlamda çalışmada aşağıdaki sorulara yanıt aranmıştır:

1. Karakterlerin isimleri "güç ve kahramanlık" anlamını çağrıştırmakta mıdır? Bu çağrışım cinsiyete göre farklılaşmakta mıdır?

2. Çizgi filmde yer alan meslek gruplarının cinsiyete göre dağılımı nasıldır?

3. Karakterlerin oyun/oyuncak seçimleri cinsiyete göre farklılaşmakta mıdır?

4. Anne ve baba karakterlerinin günlük yaşam faaliyetleri cinsiyete göre farklılaşmakta mıdır?

\section{Yöntem}

\subsection{Araştırmanın Deseni}

$\mathrm{Bu}$ araştırmada Pırıl adlı çizgi filmin toplumsal cinsiyet rolleri açısından detaylı bir şekilde incelenmesi amaçlanmaktadır. Bu nedenle, araştırma nitel ve betimsel bir özellik taşımaktadır. Araştırma yöntemi olarak ise doküman incelemesinden yararlanılmıştır. Yıldırım ve Şimşek'e (2016: 190) göre doküman incelemesi yoluyla araştırılmak istenen konu hakkında bilgi veren yazılı materyaller analiz edilmektedir. Belirli yazılı kaynakların yanı sıra filmler, fotoğraflar ve videolar gibi görsel unsurlar da doküman incelemesi ile değerlendirilmektedir.

\section{2. Çizgi Filmin Seçimi ve Tanıtılması}

$\mathrm{Bu}$ çalışmada toplumsal cinsiyet rolleri bağlamında incelenmek üzere seçilen çizgi film Pırıl'dır. Çizgi filmin 
seçiminde, toplumsal cinsiyetin kadın-erkek rollerini kapsadığ1 ve erken dönemde anne, baba, kardeş çerçevesinde ele alındığı düşünülmüş; çizgi filmde bu temaların ve karakterlerin yer almasına dikkat edilmiştir. Pırıl çizgi filminin toplumsal cinsiyet rolleri bakımından incelenmek istenmesinin ilk sebebi, araştırmanın yapıldığ 1 dönemde bu çizgi filmin televizyonda yayınlanıyor olması ve Youtube kanalında yüksek bir görüntülemeye ulaşmasıdır. Pırıl çizgi filmi, ilk olarak 2019 yılında yayınlanmaya başlanmış olup halen TRT Çocuk kanalında gösterimine devam etmektedir. Ayrıca, çizgi filmin bir Youtube kanalı da bulunmaktadır. Prrıl Youtube kanalı, izleyiciler tarafindan 187.501.980 kere görüntülenmiştir (bkz., Pırıl, 2020). Tamamen yerli yapım ürünü olan Pırıl, okul öncesi ve ilkokul grubuna hitap etmektedir. Bununla birlikte çizgi film, Youtube tarafından verilen bir ödüle de sahiptir (Tarnet, 2020).

Çizgi filmin 2019-2020 yıllarını kapsayan toplam 30 bölümü bulunmaktadır. Tüm bölümler, bu araştırmanın çalışma evrenini oluşturmaktadır. Bölüm süreleri yaklaşı 10-15 dakika arasında değişmektedir.

Pırıl çizgi filmi, 9 yaşında bir çocuğun ve arkadaşlarının, okuldaki bilgilerin günlük yaşamda karşılık bulmasını ve matematiğin aslında keyifli bir ders olduğunu keşfettikleri bir konu alanını kapsamaktadır. Çizgi filmin ana karakteri olan Pırıl, arkadaşları tarafından sevilen, eğlenceli, öğrenme hevesi olan ve matematiğe zamanla ilgi duymaya başlayan bir çocuktur. Çizgi filmdeki diğer karakterler, Pırıl'ın annesi ve babası, kardeşi Uzay, öğretmeni İpek, okul arkadaşları Ada, Cesur, Nazlı, Efe, Deha ve kardeşinin arkadaşı Mert'tir (Atf Stüdyoları, 2020).

\section{3. İşlem Yolu}

Araştırma kapsamında ilk olarak Mart-Haziran 2020 tarihleri arasında her bir bölüme internet yoluyla erişilmiş, bölümler araştırmacılar tarafından indirilip arşivlenmiştir.

Araştırmada, veriler çizgi filmin bölümlerinden elde edilmiştir. Elde edilen verilerin analizinde ise içerik analizinden yararlanılmıştır. İçerik analizi ile insan davranışlarını, tutumlarını, değerlerini kapsayan görsel veya yazılı iletiler ortaya çıkarılmakta ve sayısallaştırılmaktadır (Fraenkel vd., 2012: 478).

Verilerin analiz sürecinde filmde yer alan karakterlerin özellikleri, anne-baba rollerine ilişkin ayrıntılar ve çizgi filmde yer alan diyaloglar incelenmiş, yer alan baskın toplumsal cinsiyet temaları (karakter isimlerinin çağrıştırdığı anlamlar, meslek grupları, oyun/oyuncak seçimi, günlük yaşam faaliyetleri) belirlenmiştir. Kodlamalar, elde edilen temalardan yola çıkılarak oluşturulmuş, analiz edilmiş ve sayısallaştırılmıştır. Sayısallaştırma sürecinde belirlenen temaların kaç bölümde veya ne oranda yer aldığı yüzde ve frekans analizi ile belirlenmiştir ve elde edilen bulgular tablolaştırılmıştır. Yüzdeler arası farkın istatistiksel olarak anlamlı olup olmadığı, nitel değişkenlerde kullanılan iki yüzde arasındaki farkın önemliliği testi (T.C. Millî Eğitim Bakanlığı, 2012: 23) ile belirlenmiştir.

Güvenirliğin sağlanabilmesi için çizgi filmin bölümleri araştırmacılar tarafından en az iki defa seyredilmiştir. Bununla birlikte çizgi filmin \%10'una karşılık gelen ve rastgele seçilen üç (3) bölüm farklı bir araştırmacı tarafından aynı temalar kapsamında kodlanmıştır. Miles ve
Huberman'ın (1994) belirlediği Görüş birliği / (Görüş birliği+Görüş ayrılığı) X 100 formülü ile kodlayıcılar arasındaki uyum oranı .97 olarak hesaplanmıştır.

\section{Bulgular}

$\mathrm{Bu}$ araştırmada elde edilen bulgular, karakter isimlerinin çağrıştırdığı anlamlar, meslek grupları, oyun/oyuncak seçimi ve anne-baba rolündeki karakterlerin günlük yaşam faaliyetleri olmak üzere dört başlıkta sunulmuştur.

\subsection{Karakter İsimlerinin Çağrıştırdığı Anlamlar}

Tablo 1 incelendiğinde sekiz çocuk arasından "güç ve kahramanlık" anlamı çağrıştıran isimlerin tümünün erkek çocuklarına (Efe, Cesur ve Mert) verilen isimler olduğu görülmektedir. Öte yandan, gerçekleştirilen iki yüzde arasındaki farkın önemliliği testi sonucunda kız ve erkek çocuklarının güç ve kahramanlık çağrıştıran isim yüzdeleri arasında istatistiksel olarak anlamlı bir fark görülmemiştir ( $t$ $=1.69, \mathrm{sd}=6, p>.05)$.

Tablo 1. Güç / Kahramanlık Çağrıştıran Karakter İsimlerinin Cinsiyete Göre Dağılımı

\begin{tabular}{|c|c|c|c|c|c|c|}
\hline \multirow[t]{2}{*}{ Tema } & \multirow[t]{2}{*}{$\begin{array}{l}\text { Kodlar (İsim } \\
\text { Çağrışımı) }\end{array}$} & \multicolumn{2}{|c|}{$\begin{array}{c}\text { Kız } \\
\text { Çocuğu }\end{array}$} & \multicolumn{2}{|c|}{$\begin{array}{c}\text { Erkek } \\
\text { Çocuğu }\end{array}$} & \multirow[t]{2}{*}{$t$} \\
\hline & & $n$ & $\%$ & $n$ & $\%$ & \\
\hline $\begin{array}{l}\text { İsimlerin } \\
\text { Çağrıştır } \\
\text { dığı } \\
\text { Anlamlar }\end{array}$ & $\begin{array}{c}\text { Güç ve } \\
\text { Kahramanlık }\end{array}$ & - & - & 3 & 60 & $1.69^{*}$ \\
\hline
\end{tabular}

\section{2. Çizgi Filmdeki Meslek Grupları}

Tablo 2'de görüldüğü üzere çizgi filmin çeşitli bölümlerinde yer alan meslek gruplarının (19 meslek grubu) çok büyük bir k1smı erkek karakterler tarafindan temsil edilmektedir. Yapılan iki yüzde arasındaki farkın önemliliği testi sonucunda çizgi filmdeki kadınların ve erkeklerin belirli bir meslekte görülme yüzdeleri arasındaki fark erkeklerin lehine istatistiksel olarak anlamlı bulunmuştur $(t=4.91, \mathrm{sd}=17, p$ $<.05)$.

Tablo 2. Çizgi Filmdeki Meslek Gruplarının Cinsiyete Göre Dağılımı

\begin{tabular}{|c|c|c|c|c|c|c|}
\hline \multirow[t]{2}{*}{ Tema } & \multirow{2}{*}{$\begin{array}{l}\text { Kodlar } \\
\text { (Meslek } \\
\text { Grupları) }\end{array}$} & \multicolumn{2}{|c|}{ Kadın } & \multicolumn{2}{|c|}{ Erkek } & \multirow[t]{2}{*}{$t$} \\
\hline & & $n$ & $\%$ & $n$ & $\%$ & \\
\hline $\begin{array}{l}\text { Meslek } \\
\text { Grupları }\end{array}$ & $\begin{array}{l}\text { Çizgi } \\
\text { Filmdeki } \\
\text { Tüm } \\
\text { Meslek } \\
\text { Grupları }\end{array}$ & 2 & 10.5 & 17 & 89.5 & $4.91 *$ \\
\hline
\end{tabular}

$* p<.05$

Çizgi filmin neredeyse her bölümünde kadın karakterlerin öğretmenlik ve ev hanımlığı yaptıkları görülmektedir. Öte yandan, çizgi filmin farklı bölümlerinde görülen itfaiyeci (Sayıların Kayboluşu, 16. bölüm), polis, ambulans görevlisi 
(Üç Basamaklı Acil Sayılar, 20. bölüm), okul müdürü, yazar (Paralarımız, 5. bölüm), veteriner (Örüntüler, 9. bölüm), bankacı (Sıraya Geç ve Sıranı Bekle, 18. bölüm) ve benzeri pek çok meslek grubu ise erkek karakterler tarafından canlandırılmaktadır.

\subsection{Oyun / Oyuncak Seçimi}

Tablo 3'e bakıldığında çizgi filmin otuz bölümü içinde topla ve robotla oynamanın sıklıkla erkek karakterler tarafından gerçekleştirildiği görülmektedir. Yapılan iki yüzde arasındaki farkın önemliliği testi sonucunda, k1z çocuklarının topla oynama yüzdeleri ve erkek çocuklarının topla oynama yüzdeleri arasındaki farkın erkeklerin lehine istatistiksel olarak anlamlı olduğu saptanmıştır $(t=2.72$, sd $=58, p<.05)$. Benzer şekilde kız ve erkek çocuklarının robotla oynama yüzdeleri arasındaki fark da erkeklerin lehine istatistiksel olarak anlamlı bulunmuştur $(t=3.16, \mathrm{sd}=$ $58, p<.05)$. Diğer oyun ve oyuncak seçimleri yüzdeleri arasında cinsiyete göre anlamlı bir fark görülmemiştir $(p>$ $.05)$.

Tablo 3. Oyun / Oyuncak Seçiminin Cinsiyete Göre Dağılımı

\begin{tabular}{llccccc}
\hline Tema & $\begin{array}{l}\text { Kodlar } \\
\text { (Eylem- } \\
\text { ler) }\end{array}$ & $\begin{array}{c}\text { Kız } \\
\text { Çocuğu }\end{array}$ & $\begin{array}{c}\text { Erkek } \\
\text { Çocuğu }\end{array}$ & $\boldsymbol{t}$ \\
\hline & Top & 4 & 13.3 & 13 & 43.3 & $2.72^{*}$ \\
\hline $\begin{array}{l}\text { Oyun / } \\
\text { Oyuncak }\end{array}$ & Araba & 1 & 3.3 & 3 & 10 & 1.06 \\
Seçimi & Bebek & 2 & 6.7 & - & - & 1.49 \\
& Robot & - & - & 9 & 30 & $3.16^{*}$ \\
& Lego & 1 & 3.3 & 1 & 3.3 & - \\
\hline
\end{tabular}

$* p<.05$

Bulgularla bağlantılı olarak, çizgi filmde pembe renge ve parlak renkli elbiselere olan ilgisi ve dış görünüşüne önem verişi ile tanıtılan Nazlı, erkek çocukları kastederek "Futbol yasaklanmalı ve bu çocuklara nezaket dersi verilmeli." demiştir (Nazlı'nın Şaşırtan İşlem Yeteneği, 15. bölüm). Diğer bir bölümde, çocuklar oyun seçimi yaparken erkek çocuklarından birisi maç yapmak, kız çocuklarından birisi ise evcilik oynamak konusunda 1srarc1 olmuştur (Üç Basamaklı Acil Sayılar, 20. bölüm).

\subsection{Anne ve Baba Karakterlerinin Günlük Yaşam Faaliyetleri}

Tablo 4'te otuz bölüm içinde mutfak işlerinin çok büyük bir kısmının anne karakteri tarafından gerçekleştirildiği görülmektedir. Yapılan iki yüzde arasındaki farkın önemliliği testi sonucunda, anne ve baba karakterinin mutfak işleri yapma yüzdeleri arasında kadınların lehine istatistiksel olarak anlamlı bir farkın olduğu saptanmıștır $(t=4.73, \mathrm{sd}=$ $58, p<.05)$. Diğer faaliyetlerde ise cinsiyetler arasındaki yüzdelerin anlamlı bir fark göstermediği belirlenmiştir $(p>$ $.05)$.
Tablo 4. Anne ve Baba Karakterlerinin Günlük Yaşam Faaliyetlerinin Cinsiyete Göre Dağılımı

\begin{tabular}{llcll}
\hline Tema & $\begin{array}{l}\text { Kodlar } \\
\text { (Eylemler) }\end{array}$ & Anne & Baba & $t$
\end{tabular}

\begin{tabular}{|c|c|c|c|c|c|c|}
\hline & & $n$ & $\%$ & $n$ & $\%$ & \\
\hline \multirow{7}{*}{$\begin{array}{c}\text { Günlük } \\
\text { Yaşam } \\
\text { Faaliyet- } \\
\text { leri }\end{array}$} & Mutfak İşleri & 18 & 60 & 1 & 3.3 & $4.73^{*}$ \\
\hline & İşe Gitme & - & - & 3 & 10 & 1.82 \\
\hline & Boya Yapma & - & - & 1 & 3.3 & 1.03 \\
\hline & Alışveriş & 2 & 6.7 & 1 & 3.3 & 0.62 \\
\hline & Fatura Ödeme & - & - & 1 & 3.3 & 1.03 \\
\hline & Gazete Okuma & - & - & 3 & 10 & 1.82 \\
\hline & $\begin{array}{l}\text { Çocukla Vakit } \\
\text { Geçirme }\end{array}$ & 7 & 23.3 & 5 & 16.7 & 0.93 \\
\hline
\end{tabular}

$* p<.05$

Çizgi filmin on sekiz bölümünde anne, mutfakta yemek yaparken, kahvaltı hazırlarken ve bulaşık yıkarken görülmektedir. Örneğin bir bölümde, anne herkesi "Hadi çocuklar yemek hazır." cümlesiyle yemeğe çağırmakta; baba mutfağa geldiğinde " $\mathrm{Bu}$ ne güzel sofra, ellerine sağlık hayatım.” demektedir (Uzay’ın Doğum Günü Şifreleri, 8. bölüm). Başka bir bölümde, anne kahvaltı hazırlarken, baba kahvaltı masasında gazete okumaktadır (Yazı mı? Tura mı?, 7. bölüm). Diğer bir bölümde anne mutfakta kurabiye yaparken, baba yemek masasında oturmaktadır (Sifirın Hikayesi, 12. bölüm). Babanın mutfak işlerine yardım ettiği tek bölümde, çocukların bardaklarına süt doldurduğu görülmektedir (Örüntüler, 9. bölüm).

\section{Sonuç, Tartışma ve Öneriler}

Pırıl çizgi filminin toplumsal cinsiyet rolleri açısından incelendiği bu araştırmada, söz konusu çizgi filmdeki bazı faaliyetlerin ve tercihlerin toplumsal cinsiyet kalıpyargılarını içerdiği belirlenmiştir. Araştırma kapsamında, karakter isimlerinin güç / kahramanlık açısından değerlendirilmesine ilişkin ilk bulgunun istatistiksel olarak anlamlı olmadığı görülmüştür. Alanyazın incelendiğinde çizgi fillmlerdeki karakter isimlerinin bu kapsamda ele alındığı bir araştırmaya ulaşılamamıştır. Ancak medya okuryazarlığının değerlendir ildiği bir çalışmada katılımcılar medyada kızlara göre erkek karakterlerin daha fazla kahramanlıkla ilişkilendirildiklerini ve erkeklerin daha güçlü bir şekilde medyada sunulmasının cinsiyet kalıpyargılarının oluşumunda etkili olduğunu belirt mişlerdir (Provorova, 2015). Benzer şekilde Aley ve Hahn (2020) tarafından yapılan bir çalışmada tüm çizgi fillm afişlerinde kadın karakterlerin daha az sosyal ve küçük; erkek karakterlerin daha büyük ve fiziksel olarak güçlü gösterildikleri saptanmıştır. Bu çalışmada farklı bir sonuç elde edilmesinin ise karakter sayısının azlığından ve kullanılan istatistiki yöntemden kaynaklanabileceği düşünülmüştür. İlerideki çalışmalarda, farklı yöntemler kullanılarak çizgi filmlerde yer alan karakter isimlerinde toplumsal cinsiyetin yansımalarının olup olmadığını incelemek, bu konuda net bir görüş oluşmasını sağlayabilir.

Çalışmada ortaya çıkan ve anlamlı olduğu saptanan önemli bir bulgu, çizgi filmde yer alan meslek gruplarının çoğunlukla erkek karakterler tarafindan canlandırılmasıdır. İçlerinde polis, itfaiyeci ve okul müdürü gibi toplumda daha çok erkeklerin yapabileceği işler olarak görülen mesleklerin de yer aldığı çizgi filmde, kadınların yalnızca öğretmenlik veya ev hanımlığı yaptıkları görülmektedir. $\mathrm{Bu}$ bulgu 
alanyazınla uyumlu olup Şen (2020) tarafindan yapılan çalışmada bazı çizgi filmlerdeki erkek karakterlerin çeşitli mesleklerle ilişkilendirildikleri; kadın karakterlerin ise çoğunlukla ev hanımı olarak yer aldığı görülmektedir. Aynı araştırmadaki bir çizgi filmde ise kadın karakterin öğretmen olduğu dikkat çekmektedir. Benzer şekilde, Kalem (2019) tarafından gerçekleştirilen araştırmada çizgi filmlerdeki erkek karakterlerin çeşitli meslekleri icra ettikleri görülürken, kadın karakterlerin bir meslek sahibi olma oranlarının oldukça az olduğu saptanmıştır. Smith vd. (2012) tarafından yapılan bir çalışmada da çizgi filmlerdeki erkek karakterlerin yönetici, müdür, asker ve polis gibi mesleklerde; kadın karakterlerin ise sekreter, asistan ve model gibi mesleklerde öne çıkarıldığı görülmüştür. Aynı araştırmada, çizgi filmlerde kadın karakterlerin meslek sahibi olarak gösterilme oranları sadece \%20.3 olarak verilirken; erkek karakterlerde bu oranın \%79.7 olduğu belirtilmiştir. Bununla birlikte Pırıl çizgi filmiyle ilgili verilen bir bilgide, annenin aslında mimar olduğu ancak çocuklarıyla daha fazla vakit geçirebilmek için mesleğine bir süre ara verdiği belirtilmektedir (Atf Stüdyoları, 2020). Çizgi filmdeki bu durum, annenin çalıştığı takdirde çocuklarına yeterince ilgi gösteremeyeceğine ilişkin yaygın toplumsal cinsiyet kalıpyargısını (Adak, 2007: 144) desteklemektedir. Konuyla bağlantılı olarak, Tarhan (2020: 290) annelerin eşlerinden destek elde edememeleri, çocuklarını farklı sebeplerle bir diğerine emanet edememeleri ve benzer nedenlerle işlerine ara verdiklerini ifade etmiştir. Görüldüğü üzere, hem yurtiçi (örn., Kalem, 2019; Şen, 2020) hem de yurtdışı (örn., Smith vd., 2012) çalışmalarda konu ile ilgili benzer sonuçlar yer almaktadır. Çocukların çizgi filmlerde yer alan belirli mesleklerin yalnızca kadın ya da yalnızca erkek karakterler tarafından canlandırıldığını görmelerinin, ileride yapacakları meslek tercihlerinin niteliğini etkileyebileceği belirtilmektedir (Kalem, 2019: 71). Daha açık bir ifadeyle, bu temalara fazlaca maruz kalan çocuklar belirli meslekleri kadın ve erkek mesleği diye kategorileştirebilirler. Alabay ve Özdemir (2020) tarafindan gerçekleştirilen araştırmada, okul öncesi dönem çocuklarına belirli meslek gruplarının yer aldığı resimler gösterilmiş, çocuklar öğretmen, hemşire gibi meslekleri kadın mesleği; futbolcu, polis ve itfaiyeci gibi meslekleri de erkek mesleği olarak belirtmişlerdir. Sosyal bilişsel kariyer kuramına (Lent vd., 1994) göre çocukların kariyer hedeflerinin ve gelişimlerinin okul öncesi dönemde başladığı göz önüne alındığında bu durum, toplumsal cinsiyet eşitsizliğini dolaylı olarak besleyen bir faktör olabilir.

$\mathrm{Bu}$ çalışmada elde edilen ve istatistiksel olarak anlamlı olduğu saptanan başka bir bulgu, erkek çocuklarının sıklıkla top ve robot ile oynaması, kız çocuklarının ise bu faaliyetleri gerçekleştirme oranının erkeklerden daha az olmasıdır. Toplumda, bazı oyun ve oyuncakların belirli cinsiyetlere atfedildiği bilinmektedir. Bu nedenle, söz konusu sonucun toplumsal cinsiyet kalıpyargılarını sürdüren bir nitelik taşıdığı söylenebilir. Ana karakterin erkek olduğu Pepee çizgi filminin toplumsal cinsiyet çerçevesinde değerlendirildiği çalışma sonucunda top oynamanın çok büyük oranda erkek çocukları tarafından gerçekleştirildiği görülmüştür (Kalaycı, 2015). Benzer şekilde diğer çizgi filmlerin incelendiği araştırmalarda da top oynama ve top sektirme gibi eylemlerin erkekler tarafindan tercih edildiği dikkat çekmektedir (örn., Saraç, 2018; Yağan-Güder vd., 2017). Streiff ve Dundes (2017: 3) çizgi filmlerde erkek karakterlerin güç ile tahakkümü yansıtan futbol ve balıkçılık faaliyetleri ile ilişkilendirildiklerini belirtmişlerdir. Buna göre, çizgi filmlerde kız çocuklarının top oynarken daha az görülmesi, bu çocukları spora ilişkin her konuda çelişkiye davet edebilir. Bir diğer yönden, bu çalışma sonucunda robotla oynamanın da sıklıkla erkekler tarafından seçildiği görülmüştür. Benzer olarak, Deniz (2019) ve Şen (2020) tarafından gerçekleştirilen araştırmada bazı çizgi filmlerde erkek çocuklarının teknolojiye olan ilgileriyle ön plana çıkarıldığı ve bazı erkek çocukların kızlara oranla daha fazla robotçuluk oynadıkları saptanmıştır. Sonuç olarak, çizgi filmlerde teknoloji ve bununla ilişkili oyunlar/oyuncaklar sıklıkla erkeklerin lehine olacak şekilde ele alınmaktadır. Teknolojiye ilişkin konuların büyük oranda erkeklerle ilişkilendirildiği (Savc1, 1999: 125) düşünüldüğünde, bu sonuç da toplumsal cinsiyet kalıpyargılarını sürdürmesi ve kız çocuklarının bu alanlara ilgi duymasını etkilemesi bakımından önemli bir nitelik taşımaktadır. Şöyle ki hızla gelişen dünyada teknolojik faaliyetlerin kız çocukları ile ilişkilendirilmemesi ve çizgi filmlerde buna yönelik adımların az sayıda olması, sosyal öğrenme kuramıla (Bandura, 1977) uyumlu olarak kız çocuklarının model alarak öğrenmesini ve teknolojik faaliyetlere yönelmesini engelleyebilir. Erkeklerin robot oynamayla, kızların ise evcilikle resmedilmesi kız çocuklarında ev ve ev ile ilişkili rollere yönelme zorunluluğu uyandırabilir. Bilindiği üzere ataerkil toplum, kadınları sadece ev işleri ve çocuk bakımından sorumlu tutmakta; kadınların çalışma hayatını sınırlandırmaktadır (Özçatal, 2011: 22). Erkekler ise çalışma yaşamına aktif olarak katılmakta; özellikle de teknoloji ile ilgili meslek alanları eril bir çerçevede değerlendirilmektedir (Savc1, 1999: 131). Teknoloji erkek işi olarak ele alınmakta, kadın ise teknolojinin bir nesnesi konumunda tutulmaktadır (Özkazanç, 2010: 17). Dolayısı ile ataerkil düzenin kadınları teknolojiden uzaklaştırdığı söylenebilir. Söz konusu kalıpyargının medyada çizgi filmler aracılığıyla çocuklara sunulması da çocukların bu kalıpyargıları içselleştirerek kuşaklararası sürdürmelerine yol açacaktır. Nitekim Koçtürk (2020: 368) medyanın cinsiyetçi söylemlerle ve gösterimlerle hem toplumsal cinsiyet ayrımcılığını olağanlaştırdığını hem de bu ayrımcılığın devam etmesine ve yaygınlaşmasına hizmet ettiğini belirtmektedir. Bu sebeple çizgi filmlerde teknolojik faaliyetlerin ve oyun/oyuncakların kız çocuklarıyla da ilişkilendirilmesi toplumda bu kalıpyargı nın yıkılmasını kolaylaştırabilir.

Araştırma kapsamında incelenen ve istatistiksel olarak anlamlı olduğu belirlenen diğer bir bulgu, annenin sürekli evde görülmesi ve mutfak işlerinin yüksek oranda anne karakteri tarafından yapılıyor olmasıdır. Toplumda ev işleri, yemek yapma, bulaşık yıkama gibi eylemlerin annenin görevi olarak görülmesi nedeniyle bunun beklenen bir sonuç olduğu söylenebilir. Bu sonuç, çizgi filmlerin toplumsal cinsiyet çerçevesinde incelendiği araştırmalar (Deniz, 2019; Kalayc1, 2015; Kalem, 2019; Muratoğlu-Pehlivan, 2019; Saraç, 2018; Şen, 2020; Ünlü, 2017; Yağan-Güder vd., 2017) ile de tutarlıdır. Benzer şekilde Arima (2003) tarafından Japon çizgi filmleri üzerinde gerçekleştirilen bir araştırmada kadın karakterlerin evde yer alma oranlarının erkeklerden daha fazla olduğu görülmüştür. Erkekler, ofis çalışanı olarak gösterilirken, kadınlar ev işleriyle ilgilenen rolünde gösterilmektedirler. Buna göre, çizgi filmlerde annenin sıklıkla evde gösterilmesine, mutfak ve ev işi yaparak resmedilmesine devam edildiği söylenebilir. Tümkan'a 
(2007: 68) göre çocuklar televizyonda gördükleri bir davranışı aynen uygulamakta ve ilerleyen dönemlerde bu durumun çeşitli perspektifleri ortaya çıkmaktadır. Ekolojik sistemler kuramıyla uyumlu olarak, medyadaki geleneksel toplumsal cinsiyet rollerini yansıtan bir eylem de çocuklar tarafından aynen uygulanabilir. Ekolojik sistemler kuramı, içinde yaşanılan sosyal çevre ile insanın karşılıklı uyumunu ele almaktadır. Buna göre birey, içinde olduğu sosyal alanlardan hem etkilenmekte hem de bu alanları etkilemektedir (Bronfenbrenner, 1977: 514). Sözü edilen sosyal alanlar içerisinde yer alan makrosistemin en belirgin unsurlarından biri de medyadır (Bronfenbrenner ve Morris, 2006: 820). Dolayısı ile medyadaki herhangi bir davranış, çocukları etkileyebilir ve çocuklar söz konusu davranışı örnek alabilirler. $\mathrm{Bu}$ nedenle, annenin sürekli evde ve mutfakta resmedilmesi çocuklarda bu eylemlerin annenin sorumluluğunda olduğuna yönelik algılar geliştirmesi mümkündür. Özellikle bu temalara maruz kalan k1z çocukları, ileride mutfak işleriyle bir tek kendilerinin ilgilenmeleri gerektiğini düşünebilirler. Buradan hareketle çizgi filmde yansitılan bu eylem, toplumsal cinsiyet rolü kalıpyargılarının sürdürülmesine hizmet edebilir.

Sonuç olarak, araştırma kapsamında değerlendirilen Pırıl çizgi filmi, toplumsal cinsiyet kalıpyargılarını yansıtan bazı davranışlar ve faaliyetler barındırmaktadır. Bundan sonra yayınlanacak çizgi filmlerde eğitici özelliklerin yanında toplumsal cinsiyet eşitliğine dair iletilerin de verilmesinin çocukların gelişimleri için faydalı olacağı düşünülmektedir. Bir diğer yönden, annenin mutfak işleriyle uğraşması; babanın ise işe gitmesi ve mutfak işleriyle çok ilgilenmemesi bu çizgi filmde sıkça yer alan bir eylem olduğundan çizgi filmler oluşturulurken baba karakterlerinin mutfak işleriyle daha fazla ilgilenmesine dikkat edilmesi ve annenin mutfak/ev dışındaki ortamda daha fazla görülmesi belli görevlerin bazı cinsiyetlere atfedilmesini önleyebilir. Böylece, çocuklar ev ve mutfak işlerini annenin görevi; diğer görevleri ise babanın görevi diye ayırmaktan kaçınabilirler. Benzer şekilde, çizgi filmlerde belirli mesleklerin hem erkek karakterler hem kadın karakterler tarafından canlandırılıyor olması çocuklarda mesleklere ilişkin toplumsal cinsiyet eşitliği algısını güçlendirebilir. Çocuklar, her mesleğin her cinsiyet tarafindan tercih edilebiliyor olmasinı kavrayabilirler. Yine, bölümlerde oyun ve oyuncakların her iki cinsiyet tarafından yakın düzeyde oynanıyor olduğunun görülmesi, oyunlara atfedilen "kız oyunu" ve "erkek oyunu" ayrımının yıkılmasını kolaylaştıracaktır. Son olarak, çizgi filmlerin oluşturulma aşamasında toplumsal cinsiyet eşitliği konusunda uzman olan psikolojik danışmanlar, psikologlar, çocuk gelişimi uzmanları ve okul öncesi öğretmenleri gibi meslek mensuplarının yer alması yararlı olacaktır. Dahası, ebeveynlerin çocuklarının izledikleri çizgi filmi toplumsal cinsiyet eşitliği açısından değerlendirmeleri ve çizgi filmlerde toplumsal cinsiyet ayrımcılığına dair unsurlar gördüklerinde çocuklarının bu çizgi filmi izlemesini engellemeleri ve onlara olumlu örnekler sunmaları toplumsal cinsiyet eşitliğini destekleyen bir neslin yetişmesi açısından önemli olacaktır.

$\mathrm{Bu}$ çalışmanın nitel ve betimsel bir özellik taşıması nedensonuç ilişkisinin kurulmasını engellemekte olup çalışmanın sınırlılığını oluşturmaktadır. Belirtilen bu sınırlılıkla birlikte, bu araştırma Covid-19 pandemisi döneminde yayında olan bir çizgi filmin tüm bölümlerinin incelenmesi yönüyle güçlü bir nitelik taşımaktadır. Nitekim Radyo Televizyon
Yayıncıları Meslek Birliği (2020) tarafından yapılan bir araştırma sonucunda, Mart ayının başından itibaren televizyon izleme oranının $\% 23$ yükseldiği ve koronavirüs salgınının televizyona olan ilgiyi arttırdığı belirtilmiştir. $\mathrm{Bu}$ sonuçtan yola çıkarak, pandemi döneminde çocukların daha fazla televizyon seyredebilecekleri ve medyada yer alan içeriklerin çocukları daha yoğun etkileyebileceği söylenebilir. Çalışmanın diğer güçlü bir yönü, bulguların yüzde ve frekans analizi ile belirlenmiş olması ve ortaya çıkan farkların istatistiksel olarak anlamlı olup olmadığının incelenmesidir. $\mathrm{Bu}$ kapsamda yapılan daha önceki çalışmalara bakıldığında, çoğu çalışmada anlamlılık değerlerinin veya kodlayıcılar arası güvenirliğin belirlenmediği görülmüştür. Bu bağlamda ilgili araştırmanın bulgularının geçerlik ve güvenirlik yönünden güçlü bir yönü olduğu söylenebilir.

\section{Kaynakça}

Adak, N. (2007). Kadınların ikilemi: İş ve aile yaşamı. Sosyoloji Dergisi (Ülgen Oskay'a Armağan Özel Saylsi), 17, 137-152.

Akça, F., \& Koç-Çilekçiler, N. (2019). Okul öncesi dönemdeki çocukların en çok etkilendiği çizgi film karakterleri ve bu karakterlerle özdeşleşmelerinin yol aça bileceği dijital tehlikeler. Addicta: The Turkish Journal on Addictions, 6(2), 403-433. doi: 10.15805/addicta.2019.6.2.0053

Alabay, E., \& Özdemir, G. (2020). 36-72 aylık çocukların mesleklere yönelik oluşturdukları toplumsal cinsiyet algılar1. Turkish Studies, 15(1), 13-29. doi: 10.29228/Tur kishStudies.37370

Aley, M., \& Hahn, L. (2020). The powerful male hero: A content analysis of gender representation in posters for children's animated movies. Sex Roles, 83(7-8), 499-509. doi: 10.1007/s11199-020-01127-z

Arima, A. N. (2003). Gender stereotypes in Japanese television advertisements. Sex Roles, 49(1/2), 81-90.

Atf Stüdyolar1. (2020). http://atfstudyolari.com/animasyon/ adresinden erişilmiştir. Erişim Tarihi: 17.05.2020.

Bandura, A. (1977). Self-efficacy: Toward a unifying theory of behavioral change. Psychological Review, 84(2), 191-215.

Bem, S. L. (1981). Gender schema theory: A cognitive account of sex typing. Psychological Review, 88(4), 354-364.

Bem, S. L. (1985). Androgyny and gender schema theory: A conceptual and empirical integration. In Nebraska Symposium on Motivation, 32(1), 179-226.

Bronfenbrenner, U. (1977). Toward an experimental ecology of human development. American Psychologist, 32(7), 513-531. doi:10.1037/0003-066X.32.7.513

Bronfenbrenner, U., \& Morris, P. A. (2006). The bioecological model of human development. In W. Damon \& R. M. Lerner (Eds.), Handbook of child psychology: Vol.1. Theoretical models of human 
development (6th ed., pp. 793-828). New York, NY: Wiley.

Burger, J. M. (2006). Kişilik (Çev., İ. D. Erguvan-Sarığlu). İstanbul: Kaknüs Yayınları.

Büyükbaykal, G. (2007). Televizyonun çocuklar üzerindeki etkileri. İletişim Fakültesi Dergisi, 0(28), 31-44.

Christakis, D. A., \& Zimmerman, F. J. (2007). Violent television viewing during preschool is associated with antisocial beavior during school age. Pediatrics, 120(5), 993-999. doi: 10.1542/peds.20063244.

Deniz, A. (2019). Yerli yapım çizgi filmlerde toplumsal cinsiyet eşit(siz)liği. Yüksek Lisans Tezi. Ankara: Hacettepe Üniversitesi.

Dinçer, D. (2020). Toplumsal cinsiyet ve psikososyal gelişim. Ö. Haskan-Avcı (Ed.), Toplumsal cinsiyet: Psikolojik danışma ve rehberlikte güncel konular içinde (s. 76-108). Ankara: Nobel Yayıncilık.

Dökmen, Z. Y. (2009). Toplumsal cinsiyet: Sosyal psikolojik açıklamalar (7. bask1). İstanbul: Remzi Kitabevi.

Durutürk, B. (2020). Toplumsal cinsiyet rollerinin "Şifreleme-Deşifreleme" kuramı üzerinden değerlendiril mesi: Küreselleşme ekseninde ramazan ayında yayınlanan Coca-Cola reklamı.

Turkish Journal of Social Research/Turkiye Sosyal Araştırmalar Dergisi, 24 (1), 53-64.

Eagly, A. H. (1987). Reporting sex differences. American Psychologist, 42(7), 756-757. doi:10.1037/0003066x.42 .7.755

Ertürk-Kara, H. G. (2020). Anne-çocuk ilişkisinde risk faktörleri: Televizyona maruz kalma ve anne-çocuk oyun süresi. Eğitim ve Bilim, 45(201), 411-424.

Fraenkel, J. R., Wallen, N. E., \& Hyun, H. H. (2012). How to design and evaluate research in education (8. bask1). New York: McGraw-Hill.

Francis, B. (2010). Gender, toys and learning. Oxford Review of Education, 36(3), 325-344. doi:10.1080/03054981003732278

Gökçearslan, A. (2010). The effect of cartoon movies on children's gender development. Procedia Social and Behavioral Sciences, 2(2), 5202-5207. doi:10.1016/j. sbspro.2010.03.846

Gündüz-Kalan, Ö. (2010). Reklamda çocuğun toplumsal cinsiyet teorisi bağlamında konumlandırılışı: 'Kinder' reklam filmleri üzerine bir inceleme. İletişim Fakültesi Dergisi, 1(38), 75-89.

Haskan-Avcı, Ö., Karababa, A., \& Zencir, T. (2019). Toplumsal cinsiyet bağlamında erkek okul öncesi öğretmen adayları: Algıladıkları güçlükler ve gelecek kaygıları. Hacettepe Üniversitesi Ĕ̈itim Fakültesi Dergisi, 34(4), 1092-1106.

Kalaycı, N. (2015). Toplumsal cinsiyet eşitliği açısından bir çizgi film çözümlemesi: Pepee. Eğitim ve Bilim, 40(177), 243-270.
Kalem, B. G. (2019). Okul öncesi dönem çocuklarının en çok izledikleri çizgi filmlerde toplumsal cinsiyet kalıpyargıla rının incelenmesi. Yüksek Lisans Tezi. Ankara: Gazi Üniversitesi.

Koçtürk, N. (2020). Toplumsal cinsiyet ve çocuk istismarı ve ihmali. Ö. Haskan-Avc1 (Ed.), Toplumsal cinsiyet: Psikolojik danışma ve rehberlikte güncel konular içinde (s. 357-391). Ankara: Nobel Akademik Yayıncılık.

Leaper, C., Breed, L., Hoofman, L., \& Perlman, C. A. (2002). Variations in the gender-stereotyped content of children's television cartoon across genres. Journal of Applied Social Psychology, 32(8), 16531662. doi: 10.1111/j. 1559-18162002.tb02767.x

Lent, R. W., Brown, S. D., \& Hackett, G. (1994). Toward a unifying social cognitive theory of career and academic interest, choice, and performance. Journal of Vocational Behavior, 45(1), 79-122. doi: 10.1006/jvbe.1994.1027

Lindsey, L. L. (2015). Gender roles: A sociological perspective. New York, NY: Routledge.

Martin, C. L., Ruble, D. N., \& Szkrybalo, J. (2002). Cognitive theories of early gender development. Psychological Bulletin, 128(6), 903-933. doi:10. 1037// 0033-2909.128.6.903

Martin, R. (2017). Gender and emotion stereotypes in children's television. Journal of Broadcasting \& Electronic Media, 61(3), 499-517. doi:10. 1080/088381 51.2017.1344667

Miles, M. B., \& Huberman, A. M. (1994). Qualitative data analysis: An expanded sourcebook. California: SAGE Publications.

Muratoğlu-Pehlivan, B. (2019). Toplumsal cinsiyet rolleri açısından Türk çizgi filmlerinde anne ve baba temsili üzerine bir çalışma. Medya ve Kültürel Çalışmalar Dergisi, 1(2), 15-27.

Oakley, A. (2015). Sex, gender and society. Farnham: Ashgate Publishing Ltd.

Oruç, C., Tecim, E., \& Özyürek, H. (2011). Okul öncesi dönem çocuğunun kişilik gelişiminde rol modellik ve çizgi filmler. Ekev Akademi Dergisi, 15(48), 303-319.

Özçatal, E. Ö. (2011). Ataerkillik, toplumsal cinsiyet ve kadının çalışma yaşamına katılımı. Çankırı Karatekin Üniversitesi Iktisadi ve İdari Bilimler Fakültesi Dergisi, 1(1), 21-39.

Özkazanç, A. (2010). Bilim ve toplumsal cinsiyet. II. Kadın Hekimlik ve Kadın Să̆lığl Kongresi Kitabı, 16-22.

Pirll. (2020). https://www.youtube.com/channel/UCrOSyOx CMTuRcRUvWNCt9OA adresinden erişilmiştir. Erişim Tarihi: 17.05.2020.

Provorova, E. (2015). Media literacy education, gender, and media representations in the high school classroom. Doctoral Dissertation. USA: Temple University. 
Radyo Televizyon Yayıncıları Meslek Birliği. (2020). https://www.ratem.org/koronavirusetkisi adresinden eri-şilmiştir. Erişim Tarihi: 31.01.2021

Salkaya, A. D. (2020). Yeni medyada çocuk içerik üreticileri: Yaşam biçimi sunumu ve toplumsal cinsiyet rolleri üzerinden youtube çocuk kanalları. Yüksek Lisans Tezi. İstanbul: İstanbul Üniversitesi.

Saraç, H. (2018). Okul öncesi dönem çocuklarına yönelik çizgi filmlerde toplumsal cinsiyetin inşası: Niloya örneği. Yüksek Lisans Tezi. İstanbul: İstanbul Üniversitesi.

Savc1, İ. (1999). Toplumsal cinsiyet ve teknoloji. Ankara Üniversitesi SBF Dergisi, 54(1), 123-142.

Smith, S. L., Choueiti, M., Prescott, A., \& Pieper, K. (2012). Gender roles and occupations: A look at character attributes and job-related aspirations in film and televi sion. Geena Davis Institute on Gender in Media. http:// seejane.org/wpcontent/uploads/fullstudygende-r-roles-andoccupationsv2.pdf adresinden erişilmiştir.

Streiff, M., \& Dundes, L. (2017). From shapeshifter to Lava Monster: Gender stereotypes in Disney's Moana. Social Sciences, 6(91), 2-12. doi: 10.3390/socs ci6030091

Şen, B. (2020). Okul öncesi dönem çocuklarl tarafindan izlenen çizgi filmlerin toplumsal cinsiyet açısından incelenmesi. Doktora Tezi. Ankara: Gazi Üniversitesi.

T.C. Millî Eğitim Bakanlığı. (2012). Sağlık hizmetleri sekreterliği: Istatistiki testler, 462I00009. Ankara.

Tarhan, S. (2020). Mesleki rehberlik bağlamında toplumsal cinsiyet ve çalışma hayatı. Ö. Haskan-Avcı (Ed.), Toplumsal cinsiyet: Psikolojik danışma ve rehberlikte güncel konular içinde (s. 277-317). Ankara: Nobel Akademik Yayıncılık.

Tarnet. (2020). https://www.tarnet.com.tr/blog/tarnet/pirilodulu/ adresinden erişilmiştir Erişim Tarihi: 17.05.2020.

Tümkan, F. (2007). Televizyondaki şiddetin çocuk üzerindeki etkisi. KKTC Milli Eğitim ve Kültür
Bakanlığı Milli Ĕğitim Dergisi, 1, 65-88. http://talimterbiye.meb net.net/Dergi/4.pdf. Erişim Tarihi: 16.06. 2020.

Ünlü, A. S. (2017). Toplumsal cinsiyet rolleri bakımından TRT çocuk kanalında yayımlanan çizgi filmler. Yüksek Lisans Tezi. Erzincan: Erzincan Üniversitesi.

Walsh, A., \& Leaper, C. (2020). A content analysis of gender representations in preschool children's television. Mass Communication and Society, 23(3), 331-355. doi: 10.1080/15205436.2019.1664593

World Health Organization. (2020). Coronavirus disease (COVID-

19).https://apps.who.int/iris/bitstream/handle/1 0665/336034/nCoV-weekly-sitrep11Oct20-eng.pdf adre sinden erişilmiştir. Erişim Tarihi: 30.01.2021

Yağan-Güder, S., \& Alabay, E. (2016). 3-6 yaş arasındaki çocukların oyuncak tercihlerinin toplumsal cinsiyet bağlamında incelenmesi. Ahi Evran Üniversitesi Kırşehir Eğitim Fakültesi Dergisi, 17(2), 91-111.

Yağan-Güder, S., \& Güler-Yıldız, T. (2016). Okul öncesi dönemdeki çocukların toplumsal cinsiyet algılarında ailenin rolü. Hacettepe Üniversitesi Ë̆itim Fakültesi Dergisi, 31(2), 424-446.

Yağan-Güder, S., Ay, A., Saray, F., \& Kılıç, İ. (2017). Okul öncesi dönem çocuklarının izledikleri çizgi filmlerin toplumsal cinsiyet kalıpyargıları açısından incelenmesi: Niloya örneği. Eğitimde Nitel Araştırmalar Dergisi, 5(2), 95-110.

Yaşar, M., \& Paksoy, İ. (2011). Çizgi filmlerdeki saldırgan içerikli görüntülerin, çocukların serbest oyunları sırasındaki saldırganlık düzeylerine etkisi. Çukurova Üniversitesi Sosyal Bilimler Enstitüsü Dergisi, 20(2), 279-298.

Yıldırım, A., \& Şimşek, H. (2016). Sosyal bilimlerde nitel araştırma yöntemleri. Ankara: Seçkin Yayıncılık.

Zembat, R., \& Keleş, Z. (2012). Erken çocuklukta toplumsal cinsiyet değişmezliği ölçeği'nin Türkçe formunun geçerlik ve güvenirlik çalışması. Uluslararası Insan Bilimleri Dergisi, 9(1), 336-359. 


\section{Extended Abstract}

Gender includes tasks which are accepted as correct in a given culture and which are required of a person to do as a man or a woman (Dökmen, 2009: 20). Children realise the consistency of sex around age three, and they start to understand gender roles during this time (Zembat \& Keleş, 2012: 339). Due to their dependent status within the family and their developmental process, most children acquire this characteristic from their environment, particularly from their families. Such acquisition, which can also be called learning by observation or imitation, is based on Bandura's social learning theory (1977: 199). According to this, Bandura (1977) states that a new acquisition is gained as a result of observing someone else or by directly doing it yourself. In addition, according to social learning theory, the media, along with the family and society, plays a huge role in children's making gender-appropriate choices related to toys, activities, clothes, and professions (Gündüz-Kalan, 2010: 77).

Today, television plays an important role in children's learning lives. Although television has a significant impact on children's discovery and understanding of daily life, it also causes certain problems for their development (Büyükbaykal, 2007: 35). For instance, children have social learning through mass media; they may want to be like the characters exhibiting negative behaviours in these media (Akça \& Koç-Çilekçiler, 2019: 406). Several studies indicate that children who watch violent cartoons are likely to display violent behaviour themselves (Christakis \& Zimmerman, 2007; Yaşar \& Paksoy, 2011). Gender roles are also learned through content seen on television (MuratoğluPehlivan, 2019: 17). Children often acquire gender roles through commercials, TV series and cartoons. Especially, the fact that cartoons provide a colorful and enjoyable visual transfer and the fact that cartoon characters are in various sectors make them more preferred by children (Kalayc1, 2015: 246). In this respect, it is highly important for children's development that cartoons do not have any aspect that supports gender inequality. In some of the studies on this matter, it was pointed out that men were associated with power and physical aggression (Leaper et al., 2002; Walsh \& Leaper, 2020), and women with kind, supportive and romantic behaviors (Leaper et al., 2002). Furthermore, in other studies, it was pointed out that the mother as a character was depicted in the house and in the kitchen while the father was depicted outside of the house (Deniz, 2019; Kalayc1, 2015; Ünlü, 2017; Yağan-Güder et al., 2017). Based on this, it can be said that the elements based on traditional gender roles in cartoons affect children's cognitive and behavioral patterns such as their play-toy choices, friendship relationship, perceptions about being a parent.

Considering that the whole World has gone through the Covid-19 pandemic process since 2020 (WHO, 2020) and that children stay at home longer than usual, the tendency towards television and internet channels is increasing. In this respect, it is important to examine "Pirıl" a cartoon which received an award from Youtube and is presently on air on TRT Kids, in terms of gender roles. To this end, the aim of this study is to examine Piril in terms of gender roles (meanings invoked by the names of characters, professions, toy/game selection, daily activities of mothers/fathers).
This is a qualitative and descriptive study. The document analysis method was used in this study. Also, Prril is the selected cartoon to examine gender roles. Prrıl first aired in 2019 and is still shown on TRT Kids. There are 30 episodes aired between 2019-2020. All episodes are included in the study universe.

Within the scope of the study, each episode that aired between March-June 2020 was accessed via internet. These episodes were downloaded and archived by the researchers. Obtained data were analysed by content analysis. Themes were determined and codes were formulated. Whether there is a statistically meaningful difference in percentages was determined by the importance of percentage difference test used in qualitative variables (T. R. Ministry of Education, 2012: 23).

In the percentage difference test for the first finding, where character names are examined in terms of power and heroism, there was no statistically meaningful difference between the name percentages of girls and boys $(t=1.69$, sd $=6, p>.05)$. For the other finding where professions in cartoons are examined according to sex, there was a statistically meaningful difference in favour of boys between the percentages of men and women to be depicted having certain professions in cartoons $(t=4.91$, $\mathrm{sd}=17, p<.05)$. Similarly, in the percentage difference test for the toy/game selection of boys/girls, it was determined that the percentage difference between girls' and boy's playing with balls is statistically meaningful difference in favour of boys $(t=$ $2.72, \mathrm{sd}=58, p<.05)$. The percentage difference between girls/boys playing with robots was found to be statistically meaningful in favour of boys $(t=3.16, \mathrm{sd}=58, p<.05)$. Finally, according to the percentage difference test for the daily activities of mother-father figures in the cartoons, it was seen that there is a statistically significant difference in favour of women for the percentage of mothers and fathers performing kitchen chores $(t=4.73, \mathrm{sd}=58, p<.05)$.

In this study in which the cartoon called Prrll was examined according to gender roles, it was determined that some actions and choices in cartoons contain gender stereotypes. The mother dealing with kitchen chores and the father going out to work and not getting involved with kitchen duties are frequently seen in this cartoon. Therefore, it can prevent certain tasks to be associated with certain sexes if one pays attention to depicting fathers dealing with kitchen chores and showing mothers outside of the kitchen/house more when creating cartoons. Similarly, depicting certain professions as held by both male and female characters can strengthen children's perception of gender equality in relation to professions. Likewise, showing toys and games played by both sexes on an equal footing can help eliminate perceiving certain games as "girl game" or "boy game." Furthermore, it would be helpful to include professionals, such as psychological counsellors, psychologists, child development experts and pre-school teachers, who are experts on gender equality, when developing cartoons. Finally, it will be important for families to evaluate the cartoons that their children watch in terms of gender equality and to prevent their children from watching this cartoon when they see elements of gender discrimination in cartoons and to offer them positive examples in terms of raising a generation that supports gender equality. 